\title{
Sand and Dust Storms: Impact Mitigation
}

\author{
Nick Middleton ${ }^{1, *}$ and Utchang Kang ${ }^{2}$ \\ 1 St Anne's College, University of Oxford, Oxford OX2 6HS, UK \\ 2 The Secretariat of the United Nations Convention to Combat Desertification (UNCCD), Platz der Vereinten \\ Nationen 1, Bonn 53113, Germany; UKang@unccd.int \\ * Correspondence: nicholas.middleton@st-annes.ox.ac.uk
}

Academic Editors: Domenico M. Doronzo and Ali M Al-Dousari

Received: 15 May 2017; Accepted: 13 June 2017; Published: 17 June 2017

\begin{abstract}
Sand and dust storms (SDS) play an integral role in the Earth system but they also present a range of hazards to the environmental and economic sustainability of human society. These hazards are of considerable importance for residents of dryland environments and also affect people beyond drylands because wind erosion can occur in most environments and desert dust events often involve long-range transport over great distances ( $>1000 \mathrm{~km})$. This paper makes an assessment of the scale of SDS impacts by totalling the countries affected using an appraisal of peer-reviewed published sources, arriving at a conservative estimate that $77 \%$ of all parties to the United Nations Convention to Combat Desertification (UNCCD) are affected directly by SDS issues. We then present a synthesis of the environmental management techniques designed to mitigate SDS hazards for disaster risk reduction and review policy measures, both historical and contemporary, for SDS impact mitigation. Although many SDS hazards are well-known, the processes involved and their impacts are not all equally well-understood. Policies designed to mitigate the impacts of wind erosion in agricultural areas have been developed in certain parts of the world but policies designed to mitigate the wider impacts of SDS, including many that are transboundary, are geographically patchy and have a much shorter history. Further development and wider implementation of such policies is advocated because of the recent marked increase in wind erosion and associated dust storms in several parts of the world.
\end{abstract}

Keywords: dust storm; sand storm; aerosol; wind erosion; air quality; drylands; climate hazards

\section{Introduction}

Sand and dust storms (SDS) are atmospheric events created when small particles are blown from land surfaces. SDS occur when strong, turbulent winds flow over dry, unconsolidated, fine-grained surface materials where vegetation cover is sparse and sometimes altogether absent. These conditions are most commonly found in the world's drylands—deserts and semi-deserts-and hence this is where SDS are most frequent. Sand storms occur within the first few meters above the ground surface, but finer dust particles can be lifted much higher into the troposphere, where strong winds frequently transport them over great distances.

SDS play an integral role in the Earth system, with impacts that are numerous and wideranging $[1,2]$. These include effects on air chemistry and climate processes, soil characteristics and water quality, nutrient dynamics and biogeochemical cycling in both oceanic and terrestrial environments. All of these impacts have repercussions for human society, but people are also influenced more directly by a range of SDS hazards [3]. SDS can result in damage to crops and the removal of fertile topsoil, adversely affecting food production. Atmospheric dust can cause and/or aggravate a number of human health problems, including respiratory ailments and cardiovascular disease. Poor visibility can result in road traffic accidents. Other common forms of economic disruption include closure of transport services and cleaning of roads, houses and business premises. 
These hazards are of considerable importance for the residents of drylands but their significance is further magnified because desert dust events frequently involve long-range transport over thousands of kilometers, often taking fine particles far beyond dryland environments. These environmental and socio-economic impacts, which are frequently transboundary in effect, occur at local to global levels.

We know that SDS vary in frequency and intensity seasonally, because of droughts, and over longer timescales [4-6]. Attempts to combat wind erosion with soil conservation measures have succeeded in reducing SDS in certain parts of the world (e.g., $[7,8]$ ) but in other areas there has been a recent marked increase in wind erosion and associated dust storms. These areas include parts of the Arabian Peninsula $[9,10]$, the eastern Mediterranean [11,12], Lower Mesopotamia and adjacent regions [13], and parts of northeast Asia [14]. In some cases, the frequency and intensity of SDS have increased as a result of human activities, including soil surface disturbance, desertification and land degradation.

Given that SDS threats to livelihoods, environment and economy are likely to undermine the implementation of a broad range of the Sustainable Development Goal (SDG) targets, the United Nations General Assembly (UNGA) adopted resolutions entitled "Combatting sand and dust storms" in 2015 (A/RES/70/195) and 2016 (A/RES/71/219). These resolutions acknowledge that SDS represent a severe impediment to the sustainable development of affected developing countries and the well-being of their peoples and urge individual countries to address the challenges of SDS through relevant policy measures. The United Nations Convention to Combat Desertification (UNCCD) is playing a leading role in addressing SDS issues and helping countries to develop policy with a major focus on disaster risk reduction, as advocated by the Sendai Framework [15].

Mitigating the impacts of SDS is a central theme of such policy measures and the purpose of this paper is to review the range of actions available to mitigate the numerous impacts of SDS, to highlight areas of uncertainty and to consider some of the research priorities for the future.

\section{SDS Definitions}

There are numerous sources of small particulate matter in the atmosphere, including volcanic dust, sea salt, cosmic dust and various pollutants derived from combustion and industrial processes, but this paper refers to minerals that originate from land surfaces. These particles are commonly graded according to their size, consisting of clay-sized ( $<4$ microns), silt-sized (4-62.5 microns) and sand-sized ( 62.5 microns $-2 \mathrm{~mm}$ ) material. There is no strict distinction in the definitions of sand and dust storms, since there is a continuum of particle sizes in any storm. Generally, larger particles tend to return to the land surface soon after being entrained and atmospheric concentrations naturally diminish with distance from source areas as material in suspension is deposited downwind by wet and dry processes. Most of the particles transported more than $100 \mathrm{~km}$ from their source are $<20$ microns in diameter [16].

A dust storm is formally defined by the World Meteorological Organization (WMO) as the result of surface winds raising large quantities of dust into the air and reducing visibility at eye level $(1.8 \mathrm{~m})$ to less than $1000 \mathrm{~m}$ [17], although severe events may result in zero visibility. A less severe wind erosion event is often referred to as blowing dust. There is no equivalent formal definition of sand storms, but storms dominated by sand tend to have limited areal extent and hence localized impacts, including sand dune encroachment. Dust storms also have local impacts but their smaller particles can be transported much farther-over thousands of kilometers from source, often across international boundaries-which can bring hazardous dust haze to distant locations.

The duration of SDS events varies from a few hours to several days. Their intensity is commonly expressed in terms of the atmospheric concentration of particles and a distinction is typically highlighted between particles with diameters $<10$ microns $\left(\mathrm{PM}_{10}\right)$ and those with diameter $<2.5$ microns $\left(\mathrm{PM}_{2.5}\right)$. Atmospheric $\mathrm{PM}_{10}$ dust concentrations exceed $15,000 \mu \mathrm{g} / \mathrm{m}^{3}$ in severe events [18]. Hourly maximum $\mathrm{PM}_{2.5}$ concentrations can exceed $1000 \mu \mathrm{g} / \mathrm{m}^{3}$ during intense dust storms [19]. 
In chemical terms, the main component of the particles that make up SDS is silica, typically in the form of quartz $\left(\mathrm{SiO}_{2}\right)$. Other material commonly found in desert dust includes aluminum, iron, calcium, magnesium and potassium as well as organic matter and a range of salts, pathogenic microorganisms_-including fungi, bacteria and viruses—and anthropogenic pollutants.

\section{The Scale of SDS Impacts: Countries Affected}

There have been several attempts to assess desert dust sources globally [20-22], compiled using data from satellite borne sensors and terrestrial meteorological stations. These analyses have provided us with a good, though not perfect, understanding of where the planet's major contemporary atmospheric soil dust sources are situated. The most active sources are located in the Northern Hemisphere, mainly in a broad dryland Dust Belt that extends from the west coast of North Africa, across the Middle East, to South, Central and Northeast Asia. Drylands in the Southern Hemisphere are much less active SDS sources, despite concentrations of activity in Central Australia, Southern Africa and the Atacama in South America. These sources have significant local impacts-as does the North American Great Basin — but remain relatively minor on the global scale. There are also numerous locally significant areas of SDS activity in high-latitudes [23].

In addition to these sources, we know of numerous areas-many outside drylands-where wind erosion occurs due to human mismanagement of resources, particularly on agricultural fields and of large water bodies. For instance, soil erosion by wind is a particular threat on arable land in Europe [24], not only in semi-arid Mediterranean areas [25] but also in the temperate regions of northern countries [26]. There have also been attempts to map such areas. The global assessment of soil degradation (GLASOD) produced a world map of human-induced soil degradation, which included data on wind erosion that can be disaggregated to show a world map of human-induced wind erosion [27]. More recent assessments have also been made in certain regions, such as Europe [28].

We have considerable knowledge of long-distance desert dust transport pathways from many of these numerous sources of wind-blown surface material. Desert dust is commonly transported over thousands of kilometers through the troposphere and hence affects atmospheric, biological and geochemical conditions at great distances from dust sources. The global pattern of major dust transport pathways is depicted in Figure 1 along with estimates of emissions from major source regions and deposition to the oceans.

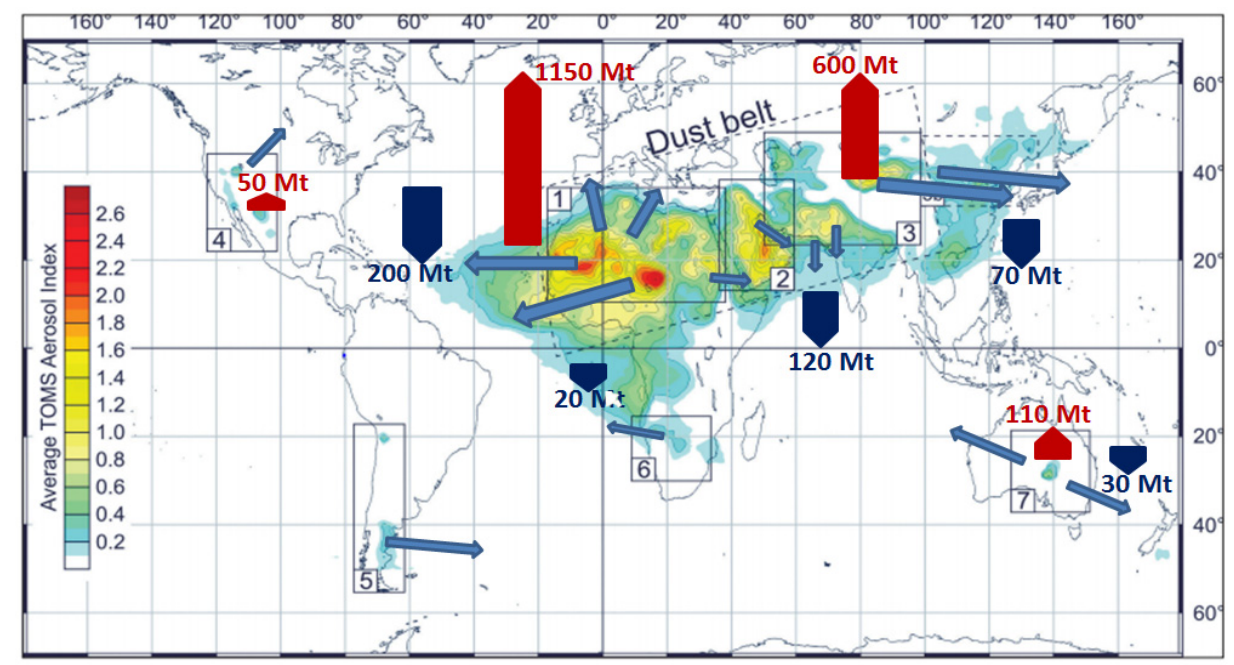

Figure 1. Main routes of desert dust transport (light blue arrows) and locations of the major dust sources: (1) Sahara; (2) Arabia; (3) Asia; (4) North America; (5) South America; (6) Southern Africa; and (7) Australia, depicted using global means of the measured daily TOMS Aerosol Index values (1979-2011). Dust emissions from different regions in Mt are indicated by red arrows and deposition to the oceans in $\mathrm{Mt}$ is indicated by dark blue arrows. Adapted and modified from [2,29]. 
Saharan dust, for instance, has been monitored across West Africa [30], as well as much further afield, including northern Europe [31], the Caucasus Mountains [32], Caribbean islands [33], North America [34], and South America [35]. Indeed, the Earth system effects of dust from the Sahara-the planet's largest source of desert dust-are plentiful. They include impacts on the atmospheric radiation balance [36], regional precipitation [37], hurricane activity [38], sea surface temperatures [39], marine primary productivity [40], health of coral reefs [41], terrestrial primary productivity [35], lake-water chemistry [42], and soil formation [33].

Dust from northeast Asian deserts, another major source, is frequently transported over the Korean Peninsula and Japan [43], across the Pacific Ocean to the North American continent [44], Europe [45] and on occasion even further [46]. Antarctica receives deposits of desert dust from Patagonia and Australia [47] and material from farmland in Ukraine has been traced to Central Europe [48].

Most of the assessments of global wind erosion sources do not feature political boundaries and, although long-distance transport is often traced from atmospheric monitoring stations via back-trajectory analysis to specific source areas, as far as we are aware, there has been no systematic attempt to assess the global distribution of SDS impacts by nation state. Figure 2 is the result of our endeavors in that direction. Using peer-reviewed published sources, we have allocated each individual party to the UNCCD (Note that there are 196 parties to the UNCCD as of the start of 2017, comprising 193 UN member states plus three others: the European Union, the Cook Islands, and Niue) to one of four categories: as a source area for SDS; as a deposition area for SDS due to long-range transport; as a country where soil erosion by wind occurs (but not on a sufficient scale to warrant inclusion in the first category); and as a country where no SDS activity or wind erosion has been recorded in peer-reviewed sources. The complete record of country parties by category is given, with supporting references, in Supplementary Material 1.

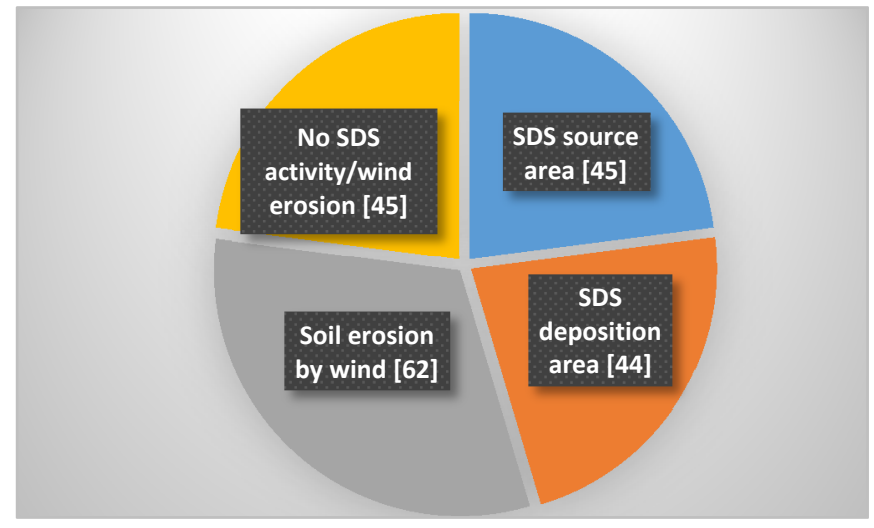

Figure 2. Number of country parties affected by SDS.

This classification of countries according to the global distribution of SDS impacts is simple and involves some degree of expert judgment, as outlined below, but it certainly indicates the globally extensive nature of SDS issues. A total of 151 country parties (77\% of all parties) are affected directly by SDS issues and 45 (23\% of all parties) are classified as SDS source areas. Most of the countries classified as SDS source areas (38 of 45) are in Africa and Asia.

The first three categories are not mutually exclusive, and many individual countries could be included in more than one category. For example, countries with SDS source areas also experience deposition of material from those sources and often also from sources elsewhere. Iran is an example, having a significant regional source in the Hamoun Basin [49] and receiving dust from several other Middle Eastern countries [50]. Some countries outside the drylands receive dust deposits only, after long distance transport of material from major sources, such as Japan which receives dust from Chinese and Mongolian deserts [51], and Panama which receives Saharan dust [52]. However, other countries receive desert dust while also experiencing some wind erosion on their own soils. Sweden is an 
example here [28,31]. In all these cases, a judgment call has been made regarding each country's most appropriate category. The USA, for instance, has been categorized as an SDS source area because it has both active sand dunes [53] and desert dust sources [54] within its territory, but the country also receives deposits of desert dust transported from sources in Mexico [55], Asia [56] and Africa [57], as well as experiencing wind erosion on its domestic agricultural soils [58]. At this point, we are not distinguishing between "good" and "bad" SDS activity. In the US case, for instance, the arrival of long-range dust from Asian sources has been investigated both for its supply of plant nutrients [59] and its adverse effects on air quality [60].

We suspect that the $77 \%$ of all parties affected directly by SDS issues is a conservative figure. This is because some of the countries where no SDS activity or wind erosion has been recorded in the peer-reviewed literature may be recipients of desert dust deposits but such deposits have simply not been catalogued or monitored. Such countries include Haiti, Liechtenstein, and Luxembourg, all of which are located in well-documented seasonal pathways of Saharan dust transport [61]. It is also worth noting that countries where no SDS activity or wind erosion has been recorded are not completely unaffected by SDS issues because all countries are impacted indirectly via the numerous effects SDS have on the Earth system.

\section{SDS Hazards and Their Mitigation}

Sand and dust storms create hazards for human society in numerous ways [1,3] and these hazards are classified in Table 1 according to the three processes of the wind erosion system: on entrainment of fine particles, during their transport, and on their deposition. SDS hazards range from local sand-blasting of agricultural crops to human health issues associated with dust haze. Indeed, SDS are a unique form of natural hazard in that the source and impact regions can be separated by great distances.

Research into these hazards varies in quality and quantity. Hazards associated with soil loss in agricultural areas are relatively well-understood and a range of mitigating soil management techniques is available. Health hazards associated with desert dust are generally well-researched but there are aspects that we do not fully understand, not least many of the causal associations between human exposure to desert dust particles and adverse health effects. The effects on various forms of transport (road, rail, air, and marine) are surprisingly little-studied and geographically, for all types of hazard, some areas of SDS activity have been subject to much greater research effort than others. Assessments of SDS impacts are also variable, and there have been relatively few attempts to assess their impacts in economic terms, although those assessments that have been made indicate that the annual cost of desert dust events in some parts of the world runs into the tens of millions if not billions of US dollars [62-65].

Table 1. Some environmental hazards to human populations caused by wind erosion and dust storms [3].

\begin{tabular}{ccc}
\hline Entrainment & Transport & Deposition \\
\hline Soil loss & Sand-blasting of crops & Salt deposition and groundwater salinization \\
Reduction of reservoir storage capacity & Drinking-water contamination \\
Nutrient, seed and fertilizer loss & Radio communication problems & Burial of structures \\
Crop root exposure & Microwave attenuation & Crop growth problems \\
Undermining structures & Transport disruption & Machinery problems \\
& Local climatic effects & Air pollution \\
& Respiratory problems and eye infections & Reduction of solar power potential \\
& Disease transmission (human) & Electrical insulator failure \\
& Disease transmission (plants and animals) & Disruption to power supplies \\
\hline
\end{tabular}

Measures to mitigate these hazards are logically classified into those designed to prevent wind erosion occurring at source and those designed to manage the adverse impacts of small particles in transport and on deposition (Figure 3). 


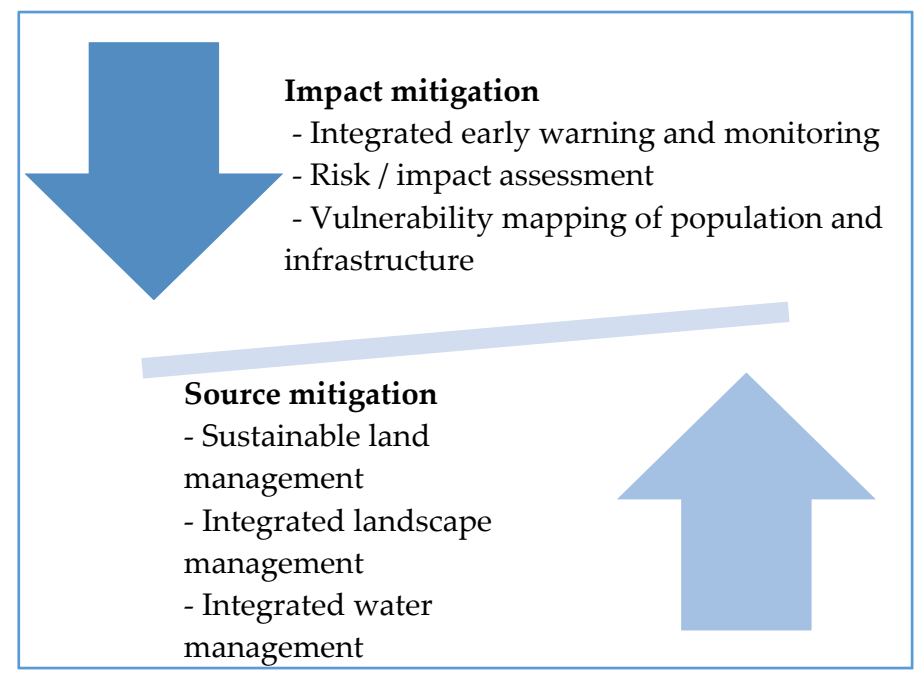

Figure 3. Two-fold approach to mitigate SDS hazards for disaster risk reduction.

\subsection{SDS Source Mitigation}

There are numerous technical means of environmental management designed to mitigate SDS at source. Most of those detailed here are usually applied in places where wind erosion is predominantly a land-use issue. The main exceptions are in desert areas where naturally-occurring mobile sand dunes and blowing sand present challenges to human activities. Preventing wind erosion in some of the very large natural sources of desert dust is not practical, so hazards deriving from such areas are better managed when the dust is in the transport or deposition phase.

SDS source mitigation can employ a wide array of techniques that have been used for wind erosion control, most developed to protect cultivated fields from soil loss [66,67]. In any particular location, a range of measures is typically employed and Riksen et al. [26] distinguish between techniques designed to minimize actual risk (short-term, e.g., cultivation practices such as minimum tillage) from those that minimize potential risk (long-term, e.g., planting windbreaks).

Action taken to mitigate anthropogenic sources of SDS contributes towards the global aspiration to halt and reverse land degradation by 2030 (Sustainable Development Goal target 15.3) and will be in line with the concept of Land Degradation Neutrality, or LDN [68]. These goals stretch over the longer-term and are synonymous with the aims of sustainable land management or SLM [69] while in many cases they also embody the ecological restoration of degraded lands. SLM in particular contributes towards the resolution of issues surrounding the need to achieve social, economic and environmental objectives in areas where productive land uses often compete with environmental and biodiversity goals: the concept of integrated landscape management [70].

\subsubsection{Controlling Wind Erosion on Cropland}

When topsoil is entrained from agricultural fields it represents a severe form of accelerated soil erosion with deleterious effects on crop yields [71] so numerous techniques to control wind erosion on cropland have been developed. They are frequently classified into three categories:

- Agronomic measures (crop management practices)

- Soil management techniques

- Protective barriers

All these measures aim to reduce erosion by decreasing the wind speed at the soil surface. This is achieved by increasing surface roughness and/or by increasing the threshold velocity that is required to initiate soil particle movement by the wind. 
Agronomic measures for controlling soil erosion use living vegetation or the residues from harvested crops to protect soil from the wind. Maintaining a sufficient vegetative cover is often referred to as the "cardinal rule" for controlling wind erosion [66]. One widely-used agronomic measure involves rotating crops grown in rows with cover crops such as grasses or legumes grown on the same field every other year. Mulching - the practice of leaving some residual crop material, such as leaves, stalks and roots, on or near the surface-is another commonly used agronomic technique. It is successful in reducing erosion and in reducing the loss of water from fields by decreasing evaporation. The relationship between soil loss and vegetation cover (live or dead) is generally exponential: the soil loss ratio is at a maximum of 1 on a bare unprotected surface but decreases rapidly to a value of approximately 0.2 with $40 \%$ soil cover [72]. However, work in Sahelian Africa has shown that maintaining a crop residue cover of just $2 \%$ on a field reduces the potential wind erosion by at least a factor of three [73].

Most soil management techniques are concerned with different methods of soil tillage, an essential management practice that provides a suitable seed bed for plant growth and helps to control weeds. Strip or zone tillage leaves protective strips of untilled land between seed rows, requiring weed control on the protective strips. Other tillage methods leave varying degrees of vegetative matter from the previous crop on the soil surface to provide protection against erosive winds. Minimum tillage incorporates the idea of stubble mulching, while zero-tillage (or no-tillage) leaves most of the soil covered with plant residues. Zero-till technology allows the farmer to lay seed in the ground at the required depth with minimal disturbance to soil structure, the specially designed machinery eliminating the need for plowing and minimizing the tillage required for planting. In addition to being very effective at controlling erosion, these forms of tillage have effectively revolutionized agriculture in many parts of the world by allowing individual farmers to manage greater areas of land with reduced energy, labor and machinery inputs [74]. Their adoption is widespread in Australia, Canada, the USA and parts of South America. In the pampa region of Argentina, zero-tillage practices are credited with improving soil fertility by reversing decades of degradation [75].

Windbreaks and shelterbelts have been used to reduce the erosive force of the wind in many agricultural areas [76,77]. Fences or walls placed at right angles to erosive winds serve this purpose, or windbreaks may be created from living plants such as trees or bushes, in which case they are known as shelterbelts. Reductions in wind velocity are achieved both upwind, for a distance of 2-5 times the height of the windbreak, and downwind, extending 10-30 times windbreak height [78]. Numerous other benefits to crops can also often be associated with the establishment of windbreaks. These include increased soil and air temperatures, reduced pest and disease problems, and an extended growing season in sheltered areas. However, windbreaks occupy space that might otherwise be used to grow crops and require maintenance to preserve their effectiveness, so they are sometimes removed to make way for irrigation developments or modern agricultural machinery.

In practice, many of these techniques to control erosion on cropland are used in combination. In a survey of villages across the southern Sahelian zone of Niger, Bielders et al. [79] recorded the use of at least 10 different low-cost wind erosion control technologies and noted that all of the techniques used also had advantages in addition to erosion control.

\subsubsection{Controlling Wind Erosion on Rangeland}

Methods for controlling wind erosion on rangelands are largely comprised of preventive measures designed to reduce the pressure of grazing. Livestock may be excluded from pastures (either permanently, for a few years, or seasonally), a ban often enforced with fencing. Alternatively, authorities may seek to reduce stocking rates, frequently by putting a cap on livestock densities with the introduction of prescribed carrying capacities per hectare in areas where grazing is allowed, although it should be noted that the notion of carrying capacity is a controversial one [80,81]. All of these measures have been introduced in various parts of China's rangelands in recent decades as 
policy instruments designed to improve the environment by restoring grassland ecology, combatting desertification and reducing dust storms [82].

\subsubsection{Controlling Blowing Sand and Mobile Desert Dunes}

The hazards associated with active sand dunes and blowing sand are addressed using engineering techniques involving fences or surface treatments. The measures typically employed, shown in Table 2, are designed to reduce impacts by encouraging the upwind deposition of sand, immobilizing susceptible surfaces, enhancing sand transport through the hazardous area, or deflecting sand movement away from the area to be protected [83]. Specific control measures are chosen depending on the local physical environment, material availability, required life expectancy of the shelter system and its economic feasibility. Reliable climatic information, particularly data on wind and precipitation, is also essential to assessing the local blowing sand hazard [84].

Table 2. Measures for controlling windblown sand and mobile sand dunes [85].

\begin{tabular}{ccc}
\hline Control Approach & Windblown sand \\
\hline $\begin{array}{c}\text { Promote deposition } \\
\text { Enhance transport } \\
\text { Reduce sand supply } \\
\text { Deflect moving sand }\end{array}$ & $\begin{array}{c}\text { Streamlining techniques; creating a smooth texture over the } \\
\text { land surface; erecting panels to deflect air flow } \\
\text { Surface stabilizing techniques; fences; vegetation } \\
\text { Fences; tree belts }\end{array}$ \\
\hline $\begin{array}{c}\text { Mechanical removal } \\
\text { Dissipation }\end{array}$ & Mobile dunes & $\begin{array}{c}\text { Bulldozing } \\
\text { Immobilization by altering aerodynamic form }\end{array}$ \\
\hline
\end{tabular}

Fences are deployed extensively in deserts to reduce sand deposition (e.g., along roads and railways) or to reduce wind erosion in an area behind the fence. These artificial structures are constructed using materials such as concrete, metal, plastic, wood, stone, or vegetation and their efficacy in trapping sand depends critically on fence height and porosity [86].

Attempts to stabilize sand dunes have been undertaken for many decades. Initial, temporary reduction in sand movement can be achieved by covering the sand surface with a mulch of some kind. Mulching with sprays of petroleum products has been a common practice in parts of the Middle East, but concerns over the release of heavy metals has spurred interest in alternatives. Primary surface stabilization can also be accomplished by stone mulching, the use of chemical stabilizers, biological crusting, or covering the sand with plastic sheets, nets and various forms of geotextiles. A review of historical and contemporary dune stabilization techniques used in the UAE is provided by Mohsin and Attia [87]. Longer term stabilization can be achieved by planting dunes with adapted grasses, shrubs or trees, and establishing a vegetation cover is often achieved in combination with a mulch in the early stages. Amiraslani and Dragovich [88] report that oil mulch is particularly effective in encouraging seed germination in sand stabilization projects in Iran. In Egypt, and many other countries, treated wastewater is used to irrigate new vegetation until established [89]. Large-scale projects may require specialized aerial seeding from low-flying aircraft, as described by Greipsson and El-Mayas [90] in Iceland.

Reed checkboards are widely used in Chinese deserts to reduce surface wind speeds over dunes while the sand is planted with xerophytic shrubs. The process is expensive in economic and labor terms so, in the Taklamakan Desert, Dong et al. [84] explain checkboards are only used along highways that are strategic for the oil industry. The key to establishing vegetation is to select appropriate plant species that will survive the early years of irrigation using often highly saline groundwater. After several decades, soil within the checkerboards typically accumulates elevated levels of silt, clay, carbon 
and nitrogen that can support a diverse vegetation canopy [91], meaning the technique can also be used for the reclamation of degraded agricultural land [92].

\subsubsection{Controlling Wind Erosion at Mining Operations}

The range of options available to mining companies to prevent dust generation from tailings dumps includes many of the techniques detailed for controlling blowing sand and mobile dunes [93]. They include wetting mine tailings with water, and physically covering or capping them with gravel, topsoil or synthetic materials, and the erection of protective barriers to act as windbreaks. In drylands where water is at a premium, chemical suppressants developed from petroleum are widely used to mitigate fugitive dust, and renewable biopolymers may offer a more sustainable alternative [94]. Stabilizing such dust-emitting surfaces can be achieved over the longer term by promoting the establishment of a vegetative cover, typically with plants that are native to the area as well as drought-, salt-, and metal-tolerant [95].

\subsubsection{Integrated SDS Control Strategies}

Effective SDS control should adopt an integrated multi-scale and multi-functional approach [96]. Control measures to protect soil and reduce wind speed at the field level must be combined with wider landscape measures to reduce wind speed, reduce sand and dust mobilization and increase deposition of sand and dust from the atmosphere. Such integrated landscape management must simultaneously identify and manage different landscape components, such as cropland, rangeland, dunefields, mines and building sites. An integrated, landscape level approach is especially important given the transboundary nature of SDS and their impacts.

A landscape approach is also critical for the management of water resources, which are relevant to SDS emissions in many ways. Water is vitally important for many of the land uses associated with anthropogenic SDS generation (cropland, rangeland, mine tailings), but there are numerous examples of diversion and/or consumptive use of surface or groundwaters that have resulted in new sources of dust storms, blowing sand and sand dune formation in and around desiccated lake beds all over the world [97]. The measures required for mitigating SDS at these sources need to be part of sustainable integrated water management strategies. These plans, at national and international levels, should take into account relevant SDS issues.

\subsection{SDS Impact Mitigation}

Actions designed to mitigate the numerous impacts of SDS associated with the transport and deposition of sand and dust are facilitated by a range of monitoring, prediction and early warning initiatives. The entrainment and transport of small particles is monitored using a combination of data from satellites, networks of lidars and radiometers, air-quality monitoring and meteorological stations [98]. All of these sources contribute data to modeling efforts, which enhance our understanding of the processes involved and are used to produce predictions and early warnings.

A diverse range of numerical models has been developed, but the prediction of dust events both on the ground and in the atmosphere continues to face a number of significant challenges owing to the complexity of the systems involved [99]. Foremost among these challenges are the relative scarcity of suitable wind erosion observations and the huge range of relevant scales needed to fully account for all of the physical processes related to dust. One national initiative designed to address some of these issues is the National Wind Erosion Research Network established in the USA in 2014 [100].

Nonetheless, numerous methods have been developed to map areas at risk from wind erosion (e.g., [101-104]) and operational dust forecasts have been developed at a number of centers around the world in recent years, many of these initiatives evolving as part of the WMO's Sand and Dust Storm Warning Advisory and Assessment System (SDS-WAS). Established in 2007, SDS-WAS works as an international network of research, operational centers and user groups such as health, aeronautical, and 
agricultural communities. More than 15 organizations provide daily dust forecasts using 14 numerical models in different geographical regions [105].

Communicating warnings of imminent dust hazards, advising on health risks and mitigation options, can be achieved through a variety of means, including media coverage and SMS text alerts. Such early warning systems can reduce the impacts of a dust event. In the transport sector, for example, airlines can activate programs to reschedule or cancel flights before passengers arrive at the airport, thus reducing cancellation costs. In South Korea, warnings of yellow dust events (HwangSa in Korean) transported across the Korean peninsula from China and Mongolia are issued by the Korea Meteorological Administration using local media and SMS text alerts issued to users who register on their air quality alert website. There are two levels of notice [106]:

- Advisory, issued when the hourly mean $\mathrm{PM}_{10}$ concentration is expected to exceed $400 \mu \mathrm{g} / \mathrm{m}^{3}$ for over $2 \mathrm{~h}$.

- Warning, issued when the hourly mean $\mathrm{PM}_{10}$ concentration is expected to exceed $800 \mu \mathrm{g} / \mathrm{m}^{3}$ for over $2 \mathrm{~h}$.

Reducing impacts also involves assessing vulnerability (identification and mapping of vulnerable populations and infrastructure/facilities), which, alongside future trend scenarios, provides critical inputs to plans to strengthen socio-economic resilience. Vulnerability can be formulated in a number of ways, but all involve three essential parameters: the stress to which a system is exposed, its sensitivity to the impacts of that exposure, and its capacity to adapt to ongoing and future exposure [107]. Our understanding of the vulnerability of landscapes to wind erosion is relatively well-developed and is addressed in detail in Section 4.1, but appreciation of the vulnerability of socio-economic systems to SDS is much less advanced [108]. That said, certain principles identified in other fields also apply to SDS hazards, particularly the understanding that poor people living in the poorest countries are especially vulnerable because they depend on natural resource-based livelihoods that are disproportionately affected by environmental change and have the weakest ability to adapt to impacts, in large part because of their poverty. Poor people in drylands, where SDS are prevalent, are particularly vulnerable. Globally, about half of all dryland inhabitants are poor, about a billion people in total, dubbed the "forgotten billion" by Middleton et al. [109] because they have habitually been neglected in development processes.

Many investigations of the health impacts associated with atmospheric soil dust agree that certain sectors of the population in all countries are particularly vulnerable to airborne and respiratory diseases. These include infants, children, pregnant women and the elderly, people with pre-existing heart and lung diseases (e.g., asthma, chronic obstructive pulmonary disease, and ischemic heart disease) and outdoor workers (e.g., laborers, athletes) in high exposure situations. However, assessments of spatial distributions of human vulnerability to SDS health effects are few and far between. Findings from studies that have been conducted, such as the investigation of Asian dust haze effects on children's respiratory health in Taipei, Taiwan [110], indicate that geographical patterns are heterogeneous and not straightforward.

Action that can help to mitigate the health impacts of atmospheric dust relies upon an understanding of how dust exposure is linked to various ailments. Although many of the causal links remain unclear, some trustworthy public health warnings can still be disseminated, such as those shown in Table 3. There is evidence to suggest that such media alerts of poor air quality do result in behavioral changes that lower exposure to air pollutants generally [111]. A similar finding has been reached in assessments of the health impacts associated with a severe dust storm in Australia. Tozer and Leys [112] highlighted the importance of Health Alert SMS and emails sent to subscribers to the local health-alert system advising of a high pollution-level event, and Merrifield et al. [113] concluded that because the dust storm and consequent public health messages had widespread media coverage, the health consequences from this dust event were likely to represent the optimal health outcomes that could be hoped for in similar future events. 
Table 3. Typical public health messages associated with dust storm conditions.

\begin{tabular}{c} 
Advice \\
\hline Avoid exposure if possible \\
Stay indoors (preferably in air conditioned buildings) \\
Do not exercise (postpone outdoor sports events) \\
Follow asthma plans and seek medical help if respiratory or cardiovascular symptoms occur \\
\hline
\end{tabular}

However, the lack of understanding of causal links that characterize our appreciation of most dust-related ailments may still have an impact on appropriate mitigation advice. The incidence of epidemics in the Sahelian zone, the so-called Meningitis Belt, certainly appears to be related to Saharan dust intrusions brought by the Harmattan [114,115], but several possible explanations have been proposed for how dust may be linked causally to the epidemics (Table 4). Should the idea that higher meningitis transmission occurs because people gather together in close proximity during dusty periods, as suggested by Remy [116], prove to be valid, then advice to stay indoors may not be appropriate.

Table 4. Possible explanations for the impact of desert dust on meningitis epidemics in West Africa [3].

\begin{tabular}{cc}
\hline Hypothesis & Reference \\
\hline $\begin{array}{c}\text { Increase in invasion rate (i.e., shift from carrier to infected status) due to high } \\
\text { dust loads and persistent low humidity damaging immune defenses in the mouth } \\
\text { and easing bacterial invasion }\end{array}$ \\
$\begin{array}{c}\text { Higher transmission levels due to changes in living habits, such as proximity of } \\
\text { individuals taking refuge from dusty winds }\end{array}$ \\
$\begin{array}{c}\text { Co-occurrence of viral respiratory infections weakening the immune system and } \\
\text { easing transmission and invasion by bacteria }\end{array}$ \\
$\begin{array}{c}\text { Neisseria bacteria, responsible for meningitis, require iron-rich dust to grow and } \\
\text { become virulent }\end{array}$ \\
\hline
\end{tabular}

In the case of meningitis in West Africa, the need for more research and a better understanding of precisely how major outbreaks are linked to dust haze from the Sahara is clear. This gap is being addressed by the Meningitis Environmental Risk Information Technologies (MERIT) project, an effort supported by several international organizations including WHO, WMO and the intergovernmental Group on Earth Observations (GEO). MERIT aims to improve current control strategies and provide more timely warnings of the onset of meningitis epidemics [120].

One type of dust storm that is particularly hazardous to transport is the dry thunderstorm (or "haboob") characterized by a moving wall of dust that brings atmospheric conditions of near-zero visibility. Forecasts for such storms at spatial scales of a few $\mathrm{km}$ are under development [121], but systems designed to warn drivers of dusty conditions on susceptible highways have been used on Interstate routes in the US southwest for several decades [122]. More recently, remotely controlled signs are being replaced by signs linked to in-situ sensors that detect poor-visibility conditions as they form and alert motorists via overhead electronic signs. Information on dust storms and safety, including what to do if caught driving in blowing dust, is also made available on dedicated websites (e.g., pullasidestayalive.org).

In urban landscapes, increasing vegetation cover is a long-term measure that is likely to help reduce the health problems associated with atmospheric $\mathrm{PM}_{10}$ and $\mathrm{PM}_{2.5}$ concentrations as well as biological and chemical aspects of pollution [123]. Green vegetation has the potential to reduce pollutants through filtration [124], while also regulating microclimatic conditions in a way that offers at least perceived benefits and well-being [125]. Research into the importance of urban green spaces in pollution reduction has been driven largely by health effects from industrial and vehicle emissions, but is also relevant to soil dust. One study of US cities estimated the monetary value of adverse health 
effects (i.e., mortality and morbidity) countered by urban trees: Nowak et al. [126] calculated the value of $\mathrm{PM}_{2.5}$ removal in ten cities ranged from US $\$ 1$ million to US $\$ 60$ million per year.

In the shorter term, the efficient filtration of air supply into buildings can have health benefits. Another US study found that in areas where sealed and air conditioned buildings are common, the dose-response rate for $\mathrm{PM}_{10}$ induced morbidity was lower than in areas with milder climate where open windows are used more commonly for ventilation, suggesting a safety factor created by the sealed building envelope [127]. Similar technology can be used to clean air entering sensitive manufacturing plants, such as electronics component manufacturers. Kim [128] describes how Samsung in South Korea has introduced systems to reduce the number of faults in components manufactured during SDS events.

Outdoor facilities have to use different options. Identification of appropriate cleaning/ maintenance operations for photovoltaic (PV) systems is dependent on numerous factors, including site-specific environmental and weather conditions, but Mani and Pillai [129] present a series of recommendations based on their survey of the literature. Prominent among the options is periodic cleaning and the adoption/application of dust-repelling coatings. The authors also note the balance that needs to be struck in low latitudes between the low tilt angle required for PV systems to maximize solar gain and the fact that such lower tilts accumulate higher dust deposition.

\section{Policy Measures for SDS Impact Mitigation}

The challenges associated with SDS have spawned policy responses in several parts of the world, particularly in areas that have experienced problems associated with wind erosion on agricultural land. In this section, we look at some historical examples, followed by an overview of existing policies and actions at national, regional and global levels. The emphasis is on policies with a strong SDS focus, although there are also many other relevant policies at various levels, including those aimed at land management more generally (e.g., UNCCD Regional and National Action Plans), and international air pollution policies (e.g., The Convention on Long-Range Transboundary Air Pollution).

\subsection{Policy Lessons, Failures and Inadvertent Impacts}

Wind erosion from agricultural land in the North American Great Plains peaked in the Dust Bowl era of the 1930s, when a severe drought and poor land management resulted in significant soil losses and widespread economic hardship [130]. One significant result of the catastrophic socio-ecological effects of the Dust Bowl was much greater participation of government in soil conservation and land management issues. McLeman et al. [131] have reviewed the initiatives. A national Soil Conservation Service (SCS), created in the USA in 1935, identified areas in need of remediation using aerial photography surveys and detailed soil maps. The SCS acquired unoccupied and abandoned lands, significant dust storm sources, and used them for demonstration projects on terracing and contour plowing. Other government agencies provided subsidies to encourage improved plowing methods and funded the planting of shelterbelts on many private lands. A resettlement program was introduced to encourage owners of small farms in drier parts of the Great Plains to relocate.

Similar types of interventions, by both national and provincial government, occurred in Canada. Farmland was purchased to convert to grazing, subsidies offered to families willing to abandon farms in drought-stricken areas, and farmers encouraged to establish shelterbelts and adopt soil conservation measures [132].

The effectiveness of government interventions in land management on the North American Great Plains has been debated. In the USA, some evidence indicates that soil conservation efforts initiated in the 1930s helped reduce the scale of wind erosion when drought returned to the Great Plains in the 1950s, 1970s and 1990s [133]. Certainly many of the soil conservation practices encouraged by government agencies are still appropriate for reducing dust storm activity [134]. Indeed, much of the research into soil conservation and land management on the Great Plains has influenced practices in many other parts of the world [135]. However, wind erosion continues on the US Great Plains 
during times of drought and the potential for land management improvements to be undermined by other policies was highlighted by McCauley et al. [136] who attributed part of the blame for a severe dust storm in 1977 to new government incentives to cultivate marginal land. Recent work by Hand et al. [137] indicates that fine airborne dust loads $\left(\mathrm{PM}_{2.5}\right)$ in central and northern parts of the US Great Plains have increased over the period 2000-2014.

Wind erosion also continues to be an issue during recurrent drought periods in the Canadian Prairie Provinces of Alberta, Saskatchewan and Manitoba but Fox et al. [7] detected a region-wide threshold change in dustiness after 1990 that they attribute to changes in farming practices, at least in part a result of numerous initiatives-both government and private non-profit-promoting soil conservation techniques in the 1980s, as detailed in Table 5.

Table 5. Wind erosion control initiatives on the Canadian Prairies in and around the 1980s (after [7]).

\begin{tabular}{|c|c|c|c|c|}
\hline Initiative & Year Established & Jurisdiction & Authority & Purpose/Mission \\
\hline $\begin{array}{c}\text { Alberta No-Till } \\
\text { Farmer's Association }\end{array}$ & 1978 & Alberta & Nonprofit & $\begin{array}{l}\text { Promote use of tillage practices } \\
\text { to reduce soil erosion }\end{array}$ \\
\hline $\begin{array}{c}\text { Manitoba-North } \\
\text { Dakota Zero Tillage } \\
\text { Farmer's Association } \\
\text { (MNDZTFA) }\end{array}$ & 1982 & $\begin{array}{c}\text { Manitoba, Canada, } \\
\text { and North Dakota, } \\
\text { USA }\end{array}$ & Nonprofit & $\begin{array}{l}\text { Publish information to } \\
\text { encourage zero-tillage practices }\end{array}$ \\
\hline $\begin{array}{l}\text { Alberta Conservation } \\
\text { Tillage Society }\end{array}$ & 1986 & Alberta & Nonprofit & $\begin{array}{l}\text { Develop and implement } \\
\text { innovative tillage systems }\end{array}$ \\
\hline $\begin{array}{l}\text { Saskatchewan Soil } \\
\text { Conservation } \\
\text { Association }\end{array}$ & 1987 & Saskatchewan & Nonprofit & $\begin{array}{l}\text { Promote soil conservation } \\
\text { production systems }\end{array}$ \\
\hline $\begin{array}{l}\text { Soil Conservation } \\
\text { Council of Canada }\end{array}$ & 1987 & Canada & Nonprofit & $\begin{array}{l}\text { Provide public forum for soil } \\
\text { conservation issues }\end{array}$ \\
\hline $\begin{array}{c}\text { Alberta Soil } \\
\text { Conservation Act }\end{array}$ & 1988 & Alberta & Provincial & $\begin{array}{c}\text { Impose duty on landholders to } \\
\text { protect soil resources }\end{array}$ \\
\hline $\begin{array}{c}\text { Pembina Valley } \\
\text { Conservation District }\end{array}$ & 1989 & Regional & Nonprofit & $\begin{array}{c}\text { Address concerns related to loss } \\
\text { of topsoil }\end{array}$ \\
\hline No-Till on the Prairies & 1991 & North America & Nonprofit & $\begin{array}{c}\text { Provide information to farmers } \\
\text { on adopting zero-tillage }\end{array}$ \\
\hline $\begin{array}{c}\text { Zero Tillage } \\
\text { Production Manual }\end{array}$ & 1991 & General & MNDZTFA & $\begin{array}{l}\text { Provide answers to questions } \\
\text { about zero-tillage farming }\end{array}$ \\
\hline
\end{tabular}

Technical approaches to SLM in general and soil conservation in particular are not always successful for a variety of reasons. In many cases, farmers simply do not adopt agricultural innovations. Although there are numerous possible explanations-including biophysical characteristics of the farm, farmer household characteristics, and land tenure issues-there appear to be few if any universal variables that regularly explain this phenomenon [138]. As a result, a targeted policy approach is frequently advocated in which policy mechanisms such as extension services or grants are geared to the local characteristics of an area or indeed to individual farmers and their farm operations [139].

The importance of engaging farmers as active players in conservation efforts rather than passive adopters of technologies is highlighted in projects that focus on a society's social capital as an effective way of achieving greater impacts. In the broadest sense, social capital refers to the interconnectedness among individuals in a society and considers relationships as a type of asset, and there is some evidence to suggest that social capital can both create incentives and remove barriers to the adoption of soil conservation practices [140]. Government support for social capital has been identified as an element in the success of Landcare in Australia, for example [141].

Whatever approaches are adopted to facilitate the achievement of SDS policies aimed at source mitigation, knowledge of local circumstances is always likely to be critical. One interesting illustration of this axiom is provided in a study of subsistence farmers in Niger [142]. The researchers concluded that, although wind erosion rates were very high, local farmers had to balance this realization with 
much more pressing agricultural issues such as poor soil quality, unreliable rainfall and uncertain political and economic environments.

Another facet of source mitigation that should be kept in mind is the possibility that some policy measures may not have the consequences intended. Riksen et al. [26] cite an example from wind erosion control policies in Europe where an incentive to set aside former farmland did not reduce the wind erosion risk because insufficient vegetation cover developed on the poor sandy soils.

\subsection{Contemporary National, Regional and International Plans}

A number of countries have developed government policy to help mitigate the impacts of SDS often in combination with other government aims, such as combatting desertification, improving health or wider economic objectives. In China, one of the most ambitious projects to combat desertification and control dust storms is an afforestation project, the Three Norths Forest Shelterbelt program (also known as the Great Green Wall (GGW)), launched in 1978 and not scheduled for completion until 2050 [76]. Other projects include those that focus on land uses associated with soil erosion problems, such as the Grain-for-Green program designed to convert cropland to forest and grassland [143], and the Beijing-Tianjin Sand Source Control program, a regional ecological restoration project initiated in northern parts of the country in 2000 [144] that involves a mix of measures, including grazing restrictions and the conversion of cropland to forest or grassland (though not for grazing). China also has a National Action Plan to implement the UNCCD, drawn up in 1996 and revised in 2003, and is the first country to establish a national desertification monitoring initiative as a follow-up action. The Desertification Combating Law of China was enacted in 2002.

Assessments of the efficacy of these policy developments in remediating desertification in general, and specifically in preventing SDS, indicate the complexities of managing the issues [145]. The GGW program has greatly improved vegetation cover and effectively reduced dust storm intensity in parts of northern China [8], but other researchers point to warmer temperatures and greater rainfall as being more important drivers of greening trends in the area [146], and the value of large-scale afforestation in controlling desertification and soil erosion in China has been questioned due to low tree survival rates [147]. Huang et al. [148] report that rangeland restoration programs have resulted in a systematic increase in the area of grassland in most northern and western regions, but Su et al. [149] warn that bush encroachment is an unexpected outcome of the grazing ban on sandy rangelands in Inner Mongolia.

Dust blown from China and neighboring Mongolia has greatly affected South Korea where the first Master Plan for Asian Dust Damage Prevention (2008-2012) has been developed in response. The plan involves 14 relevant governmental organizations and focuses on: (i) establishing a platform for monitoring of dust storms; (ii) developing a strategy to protect against damage; (iii) establishing the Northeast Asian sub-regional cooperation network, and (iv) strengthening disaster management nationally. The second phase of the Plan (2013-2017) adopted a precautionary approach to disaster risk management and paid particular attention to vulnerable population groups. The second plan aims to strengthen the SDS monitoring network to enhance forecast capacity, and to develop a risk management plan for vulnerable population groups and different sectors including health, food, and air transportation, and regional cooperation for SDS mitigation [150].

The regional dust problem in Northeast Asia has also prompted formulation of a Regional Master Plan for the Prevention and Control of Dust and Sandstorms in Northeast Asia, a project involving the governments of China, Japan, Mongolia and South Korea [151]. The plan has two components. Firstly, a phased program to establish a regional monitoring, forecasting and early warning network for SDS in Northeast Asia which has been realized within the WMO SDS-WAS Asia Node, with a regional center hosted by the China Meteorological Administration. The second component is an investment strategy to strengthen mitigation measures and to address root causes of SDS in the regional source areas.

Some progress has also been made towards developing a similar plan for West Asia [152]. Key objectives include strengthened cooperation among countries on solutions, research and early warning 
networks but although the plan has been developed in some detail it has not yet been implemented due to a lack of funding.

\subsection{A Policy Framework for Improving SDS Hazard Mitigation}

Following the recent resolutions from the UNGA, UNCCD has been developing a draft policy framework on SDS to assist countries and regions in developing more proactive SDS policies and better predictive mechanisms. Mitigation of SDS hazards involves actions that address both source area mitigation - the on-site issues surrounding wind erosion and sand encroachment—and mitigation of hazards brought by atmospheric dust in suspension and on deposition. The policy framework aims to establish a mode of SDS management with a major focus on disaster risk reduction, as advocated by the Sendai Framework. The ultimate goal is to reduce societal vulnerability to this recurrent hazard, using policy actions under three headings:

(1) post-impact crisis management (emergency response procedures);

(2) pre-impact governance programs to strengthen resilience, reduce vulnerability and minimize impacts (mitigation); and

(3) preparedness plans and policies.

\section{Conclusions}

The environmental effects associated with wind erosion and the movement of sand and dust through the atmosphere are numerous and wide-ranging, and include significant hazards to human populations in drylands and beyond. We conservatively estimate, using a simple review of peer-reviewed published sources, that $77 \%$ of all parties to the UNCCD are affected directly by SDS issues and $23 \%$ of all parties can be classified as SDS source areas.

Although many SDS hazards are well-known, the processes involved and their impacts are not all equally well-understood. Several areas deserve a greater research effort. Our knowledge and understanding of desert dust source regions, processes of emission and transport, remain incomplete, which means that our attempts to model desert dust movement and provide adequate forecasts that can help to mitigate impacts are imperfect. Similarly, assessments of the spatial distributions of vulnerability to SDS effects, on human health and various forms of economic activity, are scarce, a deficiency that undermines the development and implementation of effective mitigation measures. Action that can help to mitigate the health impacts of atmospheric dust also relies upon an understanding of how dust exposure is linked to various ailments and many of these causal links remain unclear.

Assessing damage caused by SDS in economic terms supplies critical input to policy development, an input that is gaining greater importance as risk management becomes the dominant approach of hazard mitigation policies. In this case, we note that there have been relatively few attempts to assess the economic burden of SDS impacts. Such assessments are of particular importance for those impacts that are transboundary in nature.

Policies designed to mitigate the impacts of wind erosion, particularly in agricultural areas, are among the most developed in certain parts of the world. These policies, and the mitigation methods they have advocated, illustrate valuable lessons - of both success and failure-for those countries seeking to develop such policies anew. Policies designed to mitigate the wider impacts of SDS, including many that are transboundary, have a shorter history, but further development and wider implementation of such policies has been advocated because of the recent marked increase in wind erosion and associated dust storms in several parts of the world. This paper has been designed to add a small additional momentum to that process of policy development.

Supplementary Materials: The following is available online at www.mdpi.com/2071-1050/9/6/1053/s1, Table S1: UNCCD parties affected by SDS. 
Acknowledgments: We recognize the support of UNCCD for portions of the research reported here. The paper has benefitted from comments made by three anonymous reviewers and an academic editor.

Author Contributions: Kang and Middleton conceived this paper; Middleton wrote the bulk of it, with critical inputs from Kang, who also designed and drew the figures.

Conflicts of Interest: The authors declare no conflict of interest.

\section{References}

1. Goudie, A.S.; Middleton, N.J. Desert Dust in the Global System; Springer: Heidelberg, Germany, 2006; ISBN 978-3-540-32354-9.

2. Shao, Y.; Wyrwoll, K.H.; Chappell, A.; Huang, J.; Lin, Z.; McTainsh, G.H.; Yoon, S. Dust cycle: An emerging core theme in Earth system science. Aeolian Res. 2011, 2, 181-204. [CrossRef]

3. Middleton, N.J. Desert dust hazards: A global review. Aeolian Res. 2017, 24, 53-63. [CrossRef]

4. Goudie, A.S.; Middleton, N.J. The changing frequency of dust storms through time. Clim. Chang. 1992, 20, 197-225. [CrossRef]

5. Moulin, C.; Lambert, C.E.; Dulac, F.; Dayan, U. Control of atmospheric export of dust from North Africa by the North Atlantic Oscillation. Nature 1997, 387, 691-694.

6. Bucher, E.H.; Stein, A.F. Large Salt Dust Storms Follow a 30-Year Rainfall Cycle in the Mar Chiquita Lake (Córdoba, Argentina). PLoS ONE 2016, 11, e0156672. [CrossRef] [PubMed]

7. Fox, T.A.; Barchyn, T.E.; Hugenholtz, C.H. Successes of soil conservation in the Canadian Prairies highlighted by a historical decline in blowing dust. Environ. Res. Lett. 2012, 7, 014008. [CrossRef]

8. Tan, M.; Li, X. Does the Green Great Wall effectively decrease dust storm intensity in China? A study based on NOAA NDVI and weather station data. Land Use Policy 2015, 43, 42-47. [CrossRef]

9. Hsu, N.C.; Gautam, R.; Sayer, A.M.; Bettenhausen, C.; Li, C.; Jeong, M.J.; Tsay, S.C.; Holben, B.N. Global and regional trends of aerosol optical depth over land and ocean using SeaWiFS measurements from 1997 to 2010. Atmos. Chem. Phys. 2012, 12, 8037-8053. [CrossRef]

10. Notaro, M.; Yu, Y.; Kalashnikova, O.V. Regime shift in Arabian dust activity, triggered by persistent Fertile Crescent drought. J. Geophys. Res. Atmos. 2015, 120, 10229-10249. [CrossRef]

11. Ganor, E.; Osetinsky, I.; Stupp, A.; Alpert, P. Increasing trend of African dust, over 49 years, in the eastern Mediterranean. J. Geophys. Res. Atmos. 2010, 115, D07201. [CrossRef]

12. Krasnov, H.; Katra, I.; Friger, M. Increase in dust storm related PM 10 concentrations: A time series analysis of 2001-2015. Environ. Pollut. 2016, 213, 36-42. [CrossRef] [PubMed]

13. Ghasem, A.; Shamsipour, A.; Miri, M.; Safarrad, T. Synoptic and remote sensing analysis of dust events in southwestern Iran. Nat. Hazards 2012, 64, 1625-1638. [CrossRef]

14. Kim, J. Transport routes and source regions of Asian dust observed in Korea during the past 40 years (1965-2004). Atmos. Environ. 2008, 42, 4778-4789. [CrossRef]

15. Aitsi-Selmi, A.; Egawa, S.; Sasaki, H.; Wannous, C.; Murray, V. The Sendai framework for disaster risk reduction: Renewing the global commitment to people's resilience, health, and well-being. Int. J. Disaster Risk Sci. 2015, 6, 164-176. [CrossRef]

16. Gillette, D.A. Environmental factors affecting dust emission by wind. In Saharan Dust: Mobilization, Transport, Deposition; Morales, C., Ed.; John Wiley \& Sons: Chichester, UK, 1979; pp. 71-91, ISBN 0-471-99680-7.

17. McTainsh, G.H.; Pitblado, J.R. Dust storms and related phenomena measured from meteorological records in Australia. Earth Surf. Process. Landf. 1987, 12, 415-424. [CrossRef]

18. Leys, J.F.; Heidenreich, S.K.; Strong, C.L.; McTainsh, G.H.; Quigley, S. PM 10 concentrations and mass transport during "Red Dawn"-Sydney 23 September 2009. Aeolian Res. 2011, 3, 327-342. [CrossRef]

19. Jugder, D.; Shinoda, M.; Sugimoto, N.; Matsui, I.; Nishikawa, M.; Park, S.U.; Chun, Y.-S.; Park, M.S. Spatial and temporal variations of dust concentrations in the Gobi Desert of Mongolia. Glob. Planet. Chang. 2011, 78, 14-22. [CrossRef]

20. Prospero, J.M.; Ginoux, P.; Torres, O.; Nicholson, S.E.; Gill, T.E. Environmental characterization of global sources of atmospheric soil dust identified with the Nimbus 7 Total Ozone Mapping Spectrometer (TOMS) absorbing aerosol product. Rev. Geophys. 2002, 40, 1002. [CrossRef] 
21. Washington, R.; Todd, M.; Middleton, N.J.; Goudie, A.S. Dust-Storm source areas determined by the Total Ozone Monitoring Spectrometer and surface observations. Ann. Assoc. Am. Geogr. 2003, 93, 297-313. [CrossRef]

22. Ginoux, P.; Prospero, J.M.; Gill, T.E.; Hsu, N.C.; Zhao, M. Global-scale attribution of anthropogenic and natural dust sources and their emission rates based on MODIS Deep Blue aerosol products. Rev. Geophys. 2012, 50, RG3005. [CrossRef]

23. Bullard, J.E.; Baddock, M.; Bradwell, T.; Crusius, J.; Darlington, E.; Gaiero, D.; Gasso, S.; Gisladottir, G.; Hodgkins, R.; McCulloch, R.; et al. High-latitude dust in the Earth system. Rev. Geophys. 2016, 54, 447-485. [CrossRef]

24. Borrelli, P.; Panagos, P.; Montanarella, L. New Insights into the Geography and Modelling of Wind Erosion in the European Agricultural Land. Application of a Spatially Explicit Indicator of Land Susceptibility to Wind Erosion. Sustainability 2015, 7, 8823-8836. [CrossRef]

25. López, M.V.; Sabre, M.; Gracia, R.; Arrue, J.L.; Gomes, L. Tillage effects on soil surface conditions and dust emission by wind erosion in semiarid Aragon (NE Spain). Soil Tillage Res. 1998, 45, 91-105. [CrossRef]

26. Riksen, M.; Brouwer, F.; de Graaff, J. Soil conservation policy measures to control wind erosion in northwestern Europe. Catena 2003, 52, 309-326. [CrossRef]

27. Middleton, N.J.; Thomas, D.S.G. World Atlas of Desertification, 2nd ed.; United Nations Environment Programme (UNEP): Nairobi, Kenya, 1997; ISBN 0-340-55512-2.

28. Borrelli, P.; Panagos, P.; Ballabio, C.; Lugato, E.; Weynants, M.; Montanarella, L. Towards a Pan-European Assessment of Land Susceptibility to Wind Erosion. Land Degrad. Dev. 2016, 27, 1093-1105. [CrossRef]

29. Varga, G. Spatio-temporal distribution of dust storms-A global coverage using NASA TOMs aerosol measurements. Hung. Geogr. Bull. 2012, 61, 275-298.

30. Sunnu, A.; Afeti, G.; Resch, F. A long-term experimental study of the Saharan dust presence in West Africa. Atmos. Res. 2008, 87, 13-26. [CrossRef]

31. Franzén, L.G.; Hjelmroos, M.; Kållberg, P.; Rapp, A.; Mattsson, J.O.; Brorström-Lundén, E. The Saharan dust episode of south and central Europe, and northern Scandinavia, March 1991. Weather 1995, 50, 313-318. [CrossRef]

32. Kutuzov, S.; Shahgedanova, M.; Mikhalenko, V.; Ginot, P.; Lavrentiev, I.; Kemp, S. High-resolution provenance of desert dust deposited on Mt. Elbrus, Caucasus in 2009-2012 using snow pit and firn core records. Cryosphere 2013, 7, 1481-1498. [CrossRef]

33. Muhs, D.R.; Budahn, J.R.; Prospero, J.M.; Carey, S.N. Geochemical evidence for African dust inputs to soils of western Atlantic islands: Barbados, the Bahamas and Florida. J. Geophys. Res. 2007, 112, F02009. [CrossRef]

34. Prospero, J.M. Long-range transport of mineral dust in the global atmosphere: Impact of African dust on the environment of the southeastern United States. Proc. Natl. Acad. Sci. USA 1999, 96, 3396-3403. [CrossRef] [PubMed]

35. Boy, J.; Wilcke, W. Tropical Andean forest derives calcium and magnesium from Saharan dust. Glob. Biogeochem. Cycles 2008, 22, GB1027. [CrossRef]

36. Slingo, A.; Ackerman, T.P.; Allan, R.P.; Kassianov, E.I.; McFarlane, S.A.; Robinson, G.J.; Barnard, J.C.; Miller, M.A.; Harries, J.E.; Russell, J.E.; et al. Observations of the impact of a major Saharan dust storm on the atmospheric radiation balance. Geophys. Res. Lett. 2006, 33, L24817. [CrossRef]

37. Yoshioka, M.; Mahowald, N.M.; Conley, A.J.; Collins, W.D.; Fillmore, D.W.; Zender, C.S.; Coleman, D.B. Impact of desert dust radiative forcing on Sahel precipitation: Relative importance of dust compared to sea surface temperature variations, vegetation changes, and greenhouse gas warming. J. Clim. 2007, 20, 1445-1467. [CrossRef]

38. Evan, A.T.; Dunion, J.; Foley, J.A.; Heidinger, A.K.; Velden, C.S. New evidence for a relationship between Atlantic tropical cyclone activity and African dust outbreaks. Geophys. Res. Lett. 2006, 33, L19813. [CrossRef]

39. Lau, K.M.; Kim, K.M. Cooling of the Atlantic by Saharan dust. Geophys. Res. Lett. 2007, 34, L23811. [CrossRef]

40. Krom, M.D.; Kress, N.; Brenner, S.; Gordon, L.I. Phosphorus limitation of primary productivity in the eastern Mediterranean Sea. Limnol. Oceanogr. 1991, 36, 424-432. [CrossRef]

41. Hayes, V.G.; Barber, R.T. African dust and the demise of Caribbean coral reefs. Geophys. Res. Lett. 2000, 27, 3029-3032.

42. Psenner, R. Living in a dusty world: Airborne dust as a key factor for alpine lakes. Water Air Soil Pollut. 1999, 112, 217-227. [CrossRef] 
43. Kashima, S.; Yorifuji, T.; Bae, S.; Honda, Y.; Lim, Y.H.; Hong, Y.C. Asian dust effect on cause-specific mortality in five cities across South Korea and Japan. Atmos. Environ. 2016, 128, 20-27. [CrossRef]

44. McKendry, I.G.; Hacker, J.P.; Stull, R.; Sakiyama, S.; Mignacca, D.; Reid, K. Long-range transport of Asian dust to the lower Fraser Valley, British Columbia, Canada. J. Geophys. Res. 2001, 106, 18361-18370. [CrossRef]

45. Grousset, F.E.; Ginoux, P.; Bory, A.; Biscaye, P.E. Case study of a Chinese dust plume reaching the French Alps. Geophys. Res. Lett. 2003, 30, 1277. [CrossRef]

46. Uno, I.; Eguchi, K.; Yumimoto, K.; Takemura, T.; Shimizu, A.; Uematsu, M.; Liu, Z.; Wang, Z.; Hara, Y.; Sugimoto, N. Asian dust transported one full circuit around the globe. Nat. Geosci. 2009, 2, 557-560. [CrossRef]

47. Li, F.; Ginoux, P.; Ramaswamy, V. Distribution, transport, and deposition of mineral dust in the Southern Ocean and Antarctica: Contribution of major sources. J. Geophys. Res. Atmos. 2008, 113, D10207. [CrossRef]

48. Birmili, W.; Schepanski, K.; Ansmann, A.; Spindler, G.; Tegen, I.; Wehner, B.; Nowak, A.; Reimer, E.; Mattis, I.; Müller, K.; et al. A case of extreme particulate matter concentrations over Central Europe caused by dust emitted over the southern Ukraine. Atmos. Chem. Phys. 2008, 8, 997-1016. [CrossRef]

49. Rashki, A.; Kaskaoutis, D.G.; Goudie, A.S.; Kahn, R.A. Dryness of ephemeral lakes and consequences for dust activity: The case of the Hamoun drainage basin, southeastern Iran. Sci. Total Environ. 2013, 463, 552-564. [CrossRef] [PubMed]

50. Cao, H.; Amiraslani, F.; Liu, J.; Zhou, N. Identification of dust storm source areas in West Asia using multiple environmental datasets. Sci. Total Environ. 2015, 502, 224-235. [CrossRef] [PubMed]

51. Sugimoto, N.; Hara, Y.; Shimizu, A.; Nishizawa, T.; Matsui, I.; Nishikawa, M. Analysis of dust events in 2008 and 2009 using the lidar network, surface observations and the CFORS model. Asia Pac. J. Atmos. Sci. 2013, 49, 27-39. [CrossRef]

52. Gross, A.; Turner, B.L.; Goren, T.; Berry, A.; Angert, A. Tracing the sources of atmospheric phosphorus deposition to a tropical rain forest in Panama using stable oxygen isotopes. Environ. Sci. Technol. 2016, 50, 1147-1156. [CrossRef] [PubMed]

53. Muhs, D.; Lancaster, N.; Skipp, G.L. Geochemical evidence for a complex origin for the Kelso dunes, Mojave National Preserve, California USA. Geomorphology 2017, 276, 222-243. [CrossRef]

54. Hahnenberger, M.; Nicoll, K. Geomorphic and land cover identification of dust sources in the eastern Great Basin of Utah, USA. Geomorphology 2014, 204, 657-672. [CrossRef]

55. Rivera, N.I.R.; Gill, T.E.; Bleiweiss, M.P.; Hand, J.L. Source characteristics of hazardous Chihuahuan Desert dust outbreaks. Atmos. Environ. 2010, 44, 2457-2468. [CrossRef]

56. Husar, R.B.; Tratt, D.M.; Schichtel, B.A.; Falke, S.R.; Li, F.; Jaffe, D.; Gasso, S.; Gill, T.; Laulainen, N.S.; Lu, F.; et al. Asian dust events of April 1998. J. Geophys. Res. Atmos. 2001, 106, 18317-18330. [CrossRef]

57. Prospero, J.M.; Nees, R.T.; Uematsu, M. Deposition rate of particulate and dissolved aluminum derived from Saharan dust in precipitation at Miami, Florida. J. Geophys. Res. Atmos. 1987, 92, 14723-14731. [CrossRef]

58. Zobeck, T.M.; Van Pelt, R.S. Wind-induced dust generation and transport mechanics on a bare agricultural field. J. Hazard. Mater. 2006, 132, 26-38. [CrossRef] [PubMed]

59. Aciego, S.M.; Riebe, C.S.; Hart, S.C.; Blakowski, M.A.; Carey, C.J.; Aarons, S.M.; Dove, N.C.; Botthoff, J.K.; Sims, K.W.W.; Aronson, E.L. Dust outpaces bedrock in nutrient supply to montane forest ecosystems. Nat. Commun. 2017, 8, 14800. [CrossRef] [PubMed]

60. Jaffe, D.; Snow, J.; Cooper, O. The 2001 Asian dust events: Transport and impact on surface aerosol concentrations in the US. Eos Trans. Am. Geophys. Union 2003, 84, 501-507. [CrossRef]

61. Middleton, N.J.; Goudie, A.S. Saharan dust: Sources and trajectories. Trans. Inst. Br. Geogr. 2001, 26, $165-181$. [CrossRef]

62. Pimentel, D.; Harvey, C.; Resosudarmo, P.; Sinclair, K.; Kurz, D.; McNair, M.; Crist, S.; Shpritz, L.; Fitton, L.; Saffouri, R.; et al. Environmental and economic costs of soil erosion and conservation benefits. Science 1995, 267, 1117-1122. [CrossRef] [PubMed]

63. Ai, N.; Polenske, K.R. Socioeconomic impact analysis of yellow-dust storms: An approach and case study for Beijing. Econ. Syst. Res. 2008, 20, 187-203. [CrossRef]

64. Jeong, D.Y. Socio-economic costs from yellow dust damages in South Korea. Korean Soc. Sci. J. 2008, 35, 1-29.

65. Meibodi, A.E.; Abdoli, G.; Taklif, A.; Morshedi, B. Economic modeling of the regional polices to combat dust phenomenon by using game theory. Procedia Econ. Financ. 2015, 24, 409-418. [CrossRef]

66. Skidmore, E.L. Wind erosion control. Clim. Chang. 1986, 9, 209-218. [CrossRef] 
67. Nordstrom, K.F.; Hotta, S. Wind erosion from crop-land in the USA: A review of problems, solutions, and prospects. Geoderma 2004, 121, 157-167. [CrossRef]

68. Akhtar-Schuster, M.; Stringer, L.C.; Erlewein, A.; Metternicht, G.; Minelli, S.; Safriel, U.; Sommer, S. Unpacking the concept of land degradation neutrality and addressing its operation through the Rio Conventions. J. Environ. Manag. 2016, 195, 4-15. [CrossRef] [PubMed]

69. Marques, M.J.; Schwilch, G.; Lauterburg, N.; Crittenden, S.; Tesfai, M.; Stolte, J.; Zdruli, P.; Zucca, C.; Petursdottir, T.; Evelpidou, N.; et al. Multifaceted impacts of sustainable land management in drylands: A review. Sustainability 2016, 8, 177. [CrossRef]

70. Sayer, J.; Sunderland, T.; Ghazoul, J.; Pfund, J.L.; Sheil, D.; Meijaard, E.; van Oosten, C. Ten principles for a landscape approach to reconciling agriculture, conservation, and other competing land uses. Proc. Natl. Acad. Sci. USA 2013, 110, 8349-8356. [CrossRef] [PubMed]

71. Larney, F.J.; Bullock, M.S.; Janzen, H.H.; Ellert, B.H.; Olson, E.C. Wind erosion effects on nutrient redistribution and soil productivity. J. Soil Water Conserv. 1998, 53, 133-140.

72. Bilbro, J.D.; Fryrear, D.W. Wind erosion losses as related to plant silhouette and soil cover. Agron. J. 1994, 86, 550-553. [CrossRef]

73. Toure, A.A.; Rajot, J.L.; Garba, Z.; Marticorena, B.; Petit, C.; Sebag, D. Impact of very low crop residues cover on wind erosion in the Sahel. Catena 2011, 85, 205-214. [CrossRef]

74. Triplett, G.B.; Dick, W.A. No-tillage crop production: A revolution in agriculture! Agron. J. 2008, 100, S-153-S-156. [CrossRef]

75. Trigo, E.; Cap, E.; Malach, V.; Villarreal, F. The Case of Zero-Tillage Technology in Argentina; International Food Policy Research Institute: Washington, DC, USA, 2009.

76. Wang, X.; Zhang, C.; Hasi, E.; Dong, Z. Has the Three Norths Forest Shelterbelt Program solved the desertification and dust storm problems in arid and semiarid China? J. Arid Environ. 2010, 74, 13-22. [CrossRef]

77. Chendev, Y.G.; Sauer, T.J.; Ramirez, G.H.; Burras, C.L. History of east European chernozem soil degradation; protection and restoration by tree windbreaks in the Russian steppe. Sustainability 2015, 7, 705-724. [CrossRef]

78. Cornelis, W.M.; Gabriels, D. Optimal windbreak design for wind-erosion control. J. Arid Environ. 2005, 61, 315-332. [CrossRef]

79. Bielders, C.L.; Alvey, S.; Cronyn, N. Wind erosion: The perspective of grass-roots communities in the Sahel. Land Degrad. Dev. 2001, 12, 57-70. [CrossRef]

80. Vetter, S. Rangelands at equilibrium and non-equilibrium: Recent developments in the debate. J. Arid Environ. 2005, 62, 321-341. [CrossRef]

81. Reid, R.S.; Fernández-Giménez, M.E.; Galvin, K.A. Dynamics and resilience of rangelands and pastoral peoples around the globe. Annu. Rev. Environ. Resour. 2014, 39, 217-242. [CrossRef]

82. Li, W.; Huntsinger, L. China's grassland contract policy and its impacts on herder ability to benefit in Inner Mongolia: Tragic feedbacks. Ecol. Soc. 2011, 16, 1. [CrossRef]

83. Wiggs, G.F.S. Geomorphological hazards in drylands. In Arid Zone Geomorphology: Process, Form and Change in Drylands, 3rd ed.; Thomas, D.S.G., Ed.; Wiley-BlackWell: Oxford, UK, 2011; pp. 583-598, ISBN 978-0-470-51908-0.

84. Dong, Z.; Chen, G.; He, X.; Han, Z.; Wang, X. Controlling blown sand along the highway crossing the Taklimakan Desert. J. Arid Environ. 2004, 57, 329-344. [CrossRef]

85. Watson, A. The control of blowing sand and mobile desert dunes. The control of wind blown sand and moving dunes: A review of the methods of sand control in deserts, with observations from Saudi Arabia. Q. J. Eng. Geol. Hydrogeol. 1985, 18, 237-252. [CrossRef]

86. Li, B.; Sherman, D.J. Aerodynamics and morphodynamics of sand fences: A review. Aeolian Res. 2015, 17, 33-48. [CrossRef]

87. Mohsin, M.A.; Attia, N.F. Inverse emulsion polymerization for the synthesis of high molecular weight polyacrylamide and its application as sand stabilizer. Int. J. Polym. Sci. 2015, 2015, 436583. [CrossRef]

88. Amiraslani, F.; Dragovich, D. Combating desertification in Iran over the last 50 years: An overview of changing approaches. J. Environ. Manag. 2011, 92, 1-13. [CrossRef] [PubMed] 
89. Loutfy, N.M. Reuse of wastewater in Mediterranean region, Egyptian experience. In Waste Water Treatment and Reuse in the Mediterranean Region; Barcelo, D., Petrovic, M., Eds.; Springer: Heidelberg, Germany, 2011; pp. 183-213, ISBN 978-3-642-18280-8.

90. Greipsson, S.; El-Mayas, H. Large-scale reclamation of barren lands in Iceland by aerial seeding. Land Degrad. Dev. 1999, 10, 185-193. [CrossRef]

91. Li, X.R.; Xiao, H.L.; He, M.Z.; Zhang, J.G. Sand barriers of straw checkerboards for habitat restoration in extremely arid desert regions. Ecol. Eng. 2006, 28, 149-157. [CrossRef]

92. Li, Y.; Cui, J.; Zhang, T.; Okuro, T.; Drake, S. Effectiveness of sand-fixing measures on desert land restoration in Kerqin Sandy Land, northern China. Ecol. Eng. 2009, 35, 118-127. [CrossRef]

93. Blight, G.E. Wind erosion of waste impoundments in arid climates and mitigation of dust pollution. Waste Manag. Res. 2008, 26, 523-533. [CrossRef] [PubMed]

94. Chen, R.; Lee, I.; Zhang, L. Biopolymer stabilization of mine tailings for dust control. J. Geotech. Geoenviron. Eng. 2014, 141, 04014100. [CrossRef]

95. Mendez, M.O.; Maier, R.M. Phytostabilization of mine tailings in arid and semiarid environments-An emerging remediation technology. Environ. Health Perspect. 2008, 116, 278-283. [CrossRef] [PubMed]

96. Liniger, H.; Studer, R.M.; Moll, P.; Zander, U. Making Sense of Research for Sustainable Land Management; Centre for Development and Environment (CDE), University of Bern, Switzerland and Helmholtz-Centre for Environmental Research GmbH-UFZ: Leipzig, Germany, 2017; ISBN 978-3-944280-98-1.

97. Gill, T.E. Eolian sediments generated by anthropogenic disturbance of playas: Human impacts on the geomorphic system and geomorphic impacts on the human system. Geomorphology 1996, 17, 207-228. [CrossRef]

98. Akhlaq, M.; Sheltami, T.R.; Mouftah, H.T. A review of techniques and technologies for sand and dust storm detection. Rev. Environ. Sci. Biotechnol. 2012, 11, 305-322. [CrossRef]

99. Benedetti, A.; Baldasano, J.M.; Basart, S.; Benincasa, F.; Boucher, O.; Brooks, M.E.; Chen, J.P.; Colarco, P.R.; Gong, S.; Huneeus, N.; et al. Operational dust prediction. In Mineral Dust: A Key Player in the Earth System; Knippertz, P., Stuut, J.B.W., Eds.; Springer: Heidelberg, Germany, 2014; pp. 223-265, ISBN 978-94-017-8978-3.

100. Webb, N.P.; Herrick, J.E.; Van Zee, J.W.; Courtright, E.M.; Hugenholtz, C.H.; Zobeck, T.M.; Okin, G.S.; Barchyn, T.E.; Billings, B.J.; Boyd, R.; et al. The National Wind Erosion Research Network: Building a standardized long-term data resource for aeolian research, modeling and land management. Aeolian Res. 2016, 22, 23-36. [CrossRef]

101. Coen, G.M.; Tatarko, J.; Martin, T.C.; Cannon, K.R.; Goddard, T.W.; Sweetland, N.J. A method for using WEPS to map wind erosion risk of Alberta soils. Environ. Model. Softw. 2004, 19, 185-189. [CrossRef]

102. Mendez, M.J.; Buschiazzo, D.E. Wind erosion risk in agricultural soils under different tillage systems in the semiarid Pampas of Argentina. Soil Tillage Res. 2010, 106, 311-316. [CrossRef]

103. Martínez-Graña, A.M.; Goy, J.L.; Zazo, C. Cartographic procedure for the analysis of aeolian erosion hazard in natural parks (Central System, Spain). Land Degrad. Dev. 2015, 26, 110-117. [CrossRef]

104. Mayaud, J.R.; Bailey, R.M.; Wiggs, G.F. A coupled vegetation/sediment transport model for dryland environments. J. Geophys. Res. Earth Surf. 2017, 122, 875-900. [CrossRef]

105. World Meteorological Organization (WMO). Sand and Dust Storm Warning Advisory and Assessment System (SDS-WAS): Science and Implementation Plan 2015-2020; WWRP Report 2015-5; Nickovic, S., Cuevas, E., Baldasano, J., Terradellas, E., Nakazawa, T., Baklanov, A., Eds.; World Meteorological Organization: Geneva, Switzerland, 2015.

106. Korea Meteorological Administration. Asian Dust Warning System. Available online: http://web.kma.go. $\mathrm{kr}$ /eng/weather/asiandust/intro.jsp (accessed on 12 June 2017).

107. Adger, W.N. Vulnerability. Glob. Environ. Chang. 2006, 16, 268-281. [CrossRef]

108. Yang, H.; Zhang, X.; Zhao, F.; Shi, P.; Liu, L. Mapping Sand-dust Storm Risk of the World. In World Atlas of Natural Disaster Risk; Springer: Berlin/Heidelberg, Germany, 2015; pp. 115-150.

109. Middleton, N.; Stringer, L.; Goudie, A.; Thomas, D. The Forgotten Billion: MDG Achievement in the Drylands; UNDP-UNCCD: New York, NY, USA, 2011.

110. Yu, H.L.; Yang, C.H.; Chien, L.C. Spatial vulnerability under extreme events: A case of Asian dust storm's effects on children's respiratory health. Environ. Int. 2013, 54, 35-44. [CrossRef] [PubMed] 
111. Wen, X.J.; Balluz, L.; Mokdad, A. Association between media alerts of air quality index and change of outdoor activity among adult asthma in six states, BRFSS, 2005. J. Community Health 2009, 34, 40-46. [CrossRef] [PubMed]

112. Tozer, P.R.; Leys, J. Dust Storms-What do they really cost? Rangel. J. 2013, 35, 131-142. [CrossRef]

113. Merrifield, A.; Schindeler, S.; Jalaludin, B.; Smith, W. Health effects of the September 2009 dust storm in Sydney, Australia: Did emergency department visits and hospital admissions increase? Environ. Health 2013, 12, 32. [CrossRef] [PubMed]

114. Thomson, M.C.; Jeanne, I.; Djingarey, M. Dust and epidemic meningitis in the Sahel: A public health and operational research perspective. IOP Conf. Ser. Earth Environ. Sci. 2009, 7, 012017. [CrossRef]

115. Garcia-Pando, C.P.; Stanton, M.C.; Diggle, P.J.; Trzaska, S.; Miller, R.L.; Perlwitz, J.P.; Baldasano, J.M.; Cuevas, E.; Ceccato, P.; Yaka, P.; et al. Soil dust aerosols and wind as predictors of seasonal meningitis incidence in Niger. Environ. Health Perspect. 2014, 122, 679-686. [CrossRef]

116. Remy, G. Les fondements écologiques de la ceinture de la méningite cérébro-spinale en Afrique Sud-saharienne. Climat et Santé 1990, 3, 7-21.

117. Moore, P.S. Meningococcal meningitis in sub-Saharan Africa: A model for the epidemic process. Clin. Infect. Dis. 1992, 14, 515-525. [CrossRef] [PubMed]

118. Mueller, J.E.; Yaro, S.; Madec, Y.; Somda, P.K.; Idohou, R.S.; Njanpop Lafourcade, B.M.; Drabo, A.; Tarnagda, Z.; Sangaré, L.; Traoré, Y.; et al. Association of respiratory tract infection symptoms and air humidity with meningococcal carriage in Burkina Faso. Trop. Med. Int. Health 2008, 13, 1543-1552. [CrossRef] [PubMed]

119. Noinaj, N.; Easley, N.C.; Oke, M.; Mizuno, N.; Gumbart, J.; Boura, E.; Evans, R.W. Structural basis for iron piracy by pathogenic Neisseria. Nature 2012, 483, 53-58. [CrossRef] [PubMed]

120. Thomson, M.C.; Firth, E.; Jancloes, M.; Mihretie, A.; Onoda, M.; Nickovic, S.; Broutin, H.; Sow, S.; Perea, W.; Bertherat, E.; et al. A climate and health partnership to inform the prevention and control of meningoccocal meningitis in sub-Saharan Africa: The MERIT initiative. In Climate Science for Serving Society; Springer: Heidelberg, Germany, 2013; pp. 459-484, ISBN 978-94-007-6691-4.

121. Vukovic, A.; Vujadinovic, M.; Pejanovic, G.; Andric, J.; Kumjian, M.J.; Djurdjevic, V.; Dacic, M.; Prasad, A.K.; El-Askary, H.M.; Paris, B.C.; et al. Numerical Simulation of 'An American Haboob'. Atmos. Chem. Phys. 2014, 14, 3211-3230. [CrossRef]

122. Burritt, B.E.; Hyers, A. Evaluation of Arizona's highway dust warning system. Geol. Soc. Am. 1981, 186, 281-292.

123. Janhäll, S. Review on urban vegetation and particle air pollution-Deposition and dispersion. Atmos. Environ. 2015, 105, 130-137. [CrossRef]

124. Hwang, H.J.; Yook, S.J.; Ahn, K.H. Experimental investigation of submicron and ultrafine soot particle removal by tree leaves. Atmos. Environ. 2011, 45, 6987-6994. [CrossRef]

125. Lafortezza, R.; Carrus, G.; Sanesi, G.; Davies, C. Benefits and well-being perceived by people visiting green spaces in periods of heat stress. Urban For. Urban Green. 2009, 8, 97-108. [CrossRef]

126. Nowak, D.J.; Hirabayashi, S.; Bodine, A.; Hoehn, R. Modeled PM 2.5 removal by trees in ten US cities and associated health effects. Environ. Pollut. 2013, 178, 395-402. [PubMed]

127. Janssen, N.A.H.; Schwartz, J.; Zanobetti, A.; Suh, H.H. Air conditioning and source-specific particles as modifiers of the effect of PM10 on hospital admissions for heart and lung disease. Environ. Health Perspect. 2002, 110, 43. [CrossRef] [PubMed]

128. Kim, J.I. Socio-Economic Impact Assessment Study of Dust; Chung-Ang University: Seoul, Korea, 2009. (In Korean)

129. Mani, M.; Pillai, R. Impact of dust on solar photovoltaic (PV) performance: Research status, challenges and recommendations. Renew. Sustain. Energy Rev. 2010, 14, 3124-3131. [CrossRef]

130. Worster, D. Dust Bowl: The Southern Plains in the 1930s; Oxford University Press: Oxford, UK, 2004; ISBN 978-01-951-7488-5.

131. McLeman, R.A.; Dupre, J.; Ford, L.B.; Ford, J.; Gajewski, K.; Marchildon, G. What we learned from the Dust Bowl: Lessons in science, policy, and adaptation. Popul. Environ. 2014, 35, 417-440. [CrossRef] [PubMed]

132. Marchildon, G.P.; Kulshreshtha, S.; Wheaton, E.; Sauchyn, D. Drought and institutional adaptation in the Great Plains of Alberta and Saskatchewan, 1914-1939. Nat. Hazards 2008, 45, 391-411. [CrossRef] 
133. Wienhold, B.J.; Power, J.F.; Doran, J.W. Agricultural accomplishments and impending concerns. Soil Sci. 2000, 165, 13-30. [CrossRef]

134. Ervin, R.T.; Lee, J.A. Impact of conservation practices on airborne dust in the southern high plains of Texas. J. Soil Water Conserv. 1994, 49, 430-437.

135. Phillips, S.T. Lessons from the dust bowl: Dryland agriculture and soil erosion in the United States and South Africa, 1900-1950. Environ. Hist. 1999, 4, 245-266. [CrossRef]

136. McCauley, J.F.; Breed, C.S.; Grolier, M.J.; Mackinnon, D.J. The US dust storm of February 1977. Geol. Soc. Am. 1981, 186, 123-148.

137. Hand, J.L.; Gill, T.E.; Schichtel, B.A. Spatial and seasonal variability in fine mineral dust and coarse aerosol mass at remote sites across the United States. J. Geophys. Res. Atmos. 2017, 122, 3080-3097. [CrossRef]

138. Knowler, D.; Bradshaw, B. Farmers' adoption of conservation agriculture: A review and synthesis of recent research. Food Policy 2007, 32, 25-48. [CrossRef]

139. Stonehouse, P.D. A targeted policy approach to inducing rates of conservation compliance in agriculture. Can. J. Agric. Econ. 1996, 44, 105-119. [CrossRef]

140. Swinton, S.M. More social capital, less erosion: Evidence from Peru's Altiplano. Presented at the Annual Meeting of the American Agricultural Economics Association, Tampa, FL, USA, 30 July-2 August 2000.

141. Sobels, J.; Curtis, A.; Lockie, S. The role of Landcare group networks in rural Australia: Exploring the contribution of social capital. J. Rural Stud. 2001, 17, 265-276. [CrossRef]

142. Warren, A.; Osbahr, H.; Batterbury, S.; Chappell, A. Indigenous views of soil erosion at Fandou Béri, southwestern Niger. Geoderma 2003, 111, 439-456. [CrossRef]

143. Lei, D.E.; Shangguan, Z.P.; Rui, L.I. Effects of the grain-for-green program on soil erosion in China. Int. J. Sediment Res. 2012, 27, 120-127.

144. Dalintai, B.; Yanbo, L.; Jianjun, C. The Eurasian Steppe: History of utilization and policies on the rangeland. In Restoring Community Connections to the Land; Fernández-Giménez, M.E., Wang, X., Baival, B., Klein, J., Reid, R., Eds.; CABI: Wallingford, UK, 2011; pp. 51-68, ISBN 97-818-459-3894-9.

145. Middleton, N. Rangeland management and climate hazards in drylands: Dust storms, desertification and the overgrazing debate. Nat. Hazards 2016, 1-14. [CrossRef]

146. Piao, S.; Friedlingstein, P.; Ciais, P.; Viovy, N.; Demarty, J. Growing season extension and its impact on terrestrial carbon cycle in the northern hemisphere over the past 2 decades. Glob. Biogeochem. 2007, 21, GB3018. [CrossRef]

147. Cao, S. Why large-scale afforestation efforts in China have failed to solve the desertification problem. Environ. Sci. Technol. 2008, 42, 1826-1831. [CrossRef] [PubMed]

148. Huang, L.; Xiao, T.; Zhao, Z.; Sun, C.; Liu, J.; Shao, Q.; Wang, J. Effects of grassland restoration programs on ecosystems in arid and semiarid China. J. Environ. Manag. 2013, 117, 268-275. [CrossRef] [PubMed]

149. Su, H.; Liu, W.; Xu, H.; Wang, Z.; Zhang, H.; Hu, H.; Li, Y. Long-term livestock exclusion facilitates native woody plant encroachment in a sandy semiarid rangeland. Ecol. Evol. 2015, 5, 2445-2456. [CrossRef] [PubMed]

150. Park, J.S.; Han, J.S.; Ahn, J.Y. The research trend of Asian dust storm (AD) of Korea and recent episode analysis. J. Korean Soc. Atmos. Environ. 2013, 29, 553-573. [CrossRef]

151. United Nations Convention to Combat Desertification (UNCCD). Regional Master Plan for the Prevention and Control of Dust and Sandstorms in North East Asia; UNCCD Secretariat: Bonn, Germany, 2005; Volume 1.

152. United Nations Office at Nairobi (UNEP). West Asia Regional Master Plan to Combat Sand and Dust Storms; UNEP: Nairobi, Kenya, 2014.

(C) 2017 by the authors. Licensee MDPI, Basel, Switzerland. This article is an open access article distributed under the terms and conditions of the Creative Commons Attribution (CC BY) license (http://creativecommons.org/licenses/by/4.0/). 